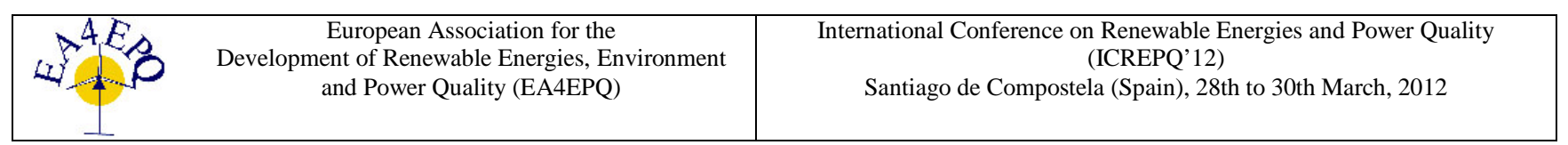

\title{
Texturization of Silicon Wafers for Solar Cells by Anisotropic Etching with Sodium Silicate Solutions
}

\author{
C.L. $\mathrm{Su}^{1}$, C.H. $\mathrm{Hsu}^{2}$, K.H. $\mathrm{Lan}^{2}$, R. Leron ${ }^{1}$, A. Soriano ${ }^{3}$ and M.H. Li ${ }^{1, *}$ \\ ${ }^{1}$ R \& D Center for Membrane Technology and Department of Chemical Engineering \\ Chung Yuan Christian University \\ 200 Chung Pei Rd., Chung Li City, 32023, Taiwan, R.O.C. \\ Phone/Fax number:+8 3265 4109/ +886 3265 4199, *e-mail: mhli@cycu.edu.tw \\ ${ }^{2}$ OMG (Asia) Electronics Chemical Company, Ltd. \\ 5-1 Chi Lin N. Rd., Chung Li City, Taoyuan, 32053, Taiwan, R.O.C. \\ ${ }^{3}$ School of Chemical Engineering and Chemistry, Mapua Institute of Technology \\ Manila, 1002, Philippines
}

\begin{abstract}
The efficiency of silicon solar cells greatly depends on the texturization of silicon wafers used in their fabrication. Texturization reduces the reflectance of the silicon surface which improves the light trapping ability of the solar cells.

In this study, aqueous $\mathrm{Na}_{2} \mathrm{SiO}_{3}$ solutions were used as etchants in the texturization of monocrystalline silicon wafers. The main objective was to evaluate the performance of the etchant based on the silicon surface reflectance. The surface morphology and etching rate were also investigated. Results showed that $\mathrm{Na}_{2} \mathrm{SiO}_{3}$ solutions reduced the surface reflectance of the wafers better than other alkaline etchants. This was brought about by the formation of uniformly distributed pyramidal structures on the surface of the wafer after texturization. The effects of process parameters such as $\mathrm{Na}_{2} \mathrm{SiO}_{3}$ concentration, solution temperature and etching time on the reflectance were evaluated and optimized by applying ANOVA and Response Surface Method (RSM). The optimum process condition was found to be $6.2 \mathrm{wt} \% \mathrm{Na}_{2} \mathrm{SiO}_{3}, 80^{\circ} \mathrm{C}$ and $5 \mathrm{~min}$ at which the reflectance of the silicon wafer was reduced to 9.27\%. Furthermore, the addition of small amounts of IPA (up to $0.03 \mathrm{wt} \%$ ) to the $\mathrm{Na}_{2} \mathrm{SiO}_{3}$ solution reduced the reflectance of the wafer (9.13\%) and slightly improved its wettability.
\end{abstract}

\section{Key words}

Anisotropic etching, monocrystalline silicon, reflectance, sodium silicate, texturization

\section{Introduction}

Texturization of the surface of $\{100\}$ monocrystalline silicon wafer by anisotropic etching is an effective means that is widely used to reduce surface reflectance and enhance light trapping in silicon solar cells. The etching process leads to the formation of $\{111\}$ pyramidal structures on the silicon surface which geometries allow light to be more easily coupled into the silicon and efficiently absorbed into the solar cell.
Anisotropic etching employs aqueous alkaline solutions of organic or inorganic compounds. Current practices usually utilize alkaline etchants which are aqueous solutions of $\mathrm{NaOH}$ or $\mathrm{KOH}$ with isopropyl alcohol (IPA) as surface-active additive. The aqueous alkaline solutions $(\mathrm{NaOH}$ or $\mathrm{KOH})$ etch the silicon surface anisotropically, producing uniform pyramid textures, while IPA tends to improve the wettability of the wafer surface [1-2]. These solutions are also preferred due to cost and time efficiency considerations. However, anisotropic etching process works with some disadvantages such as lack of pyramid size control, poor reproducibility and difficulty in controlling the concentration of IPA [3].

While more advanced techniques were claimed to have better performance than anisotropic etching, most of them still remain to be more complex and costly. Thus, significant interest has still been given to the search for novel alternative texturing solutions that are costeffective. Some of the novel etchants reported in literatures include solutions of $\mathrm{NaOH}$ and anhydrous sodium acetate [4], tetramethyl ammoniun hydroxide, TMAH [5], sodium carbonate and sodium bicarbonate [1]. In the present work, we aimed to investigate another etchant, sodium silicate $\left(\mathrm{Na}_{2} \mathrm{SiO}_{3}\right)$ solution, for its potential use in the texturization of monocrystalline silicon wafer for solar cell applications. The main objective was to evaluate the performance of the etchant based on the silicon surface reflectance and morphology and the etching rate. The effects of process parameters such as $\mathrm{Na}_{2} \mathrm{SiO}_{3}$ concentration, solution temperature and etching time on the reflectance were investigated and optimized by applying ANOVA and Response Surface Method (RSM). Furthermore, the effects of the addition of IPA to the $\mathrm{Na}_{2} \mathrm{SO}_{3}$ solution on the reflectance of the silicon wafer and its wettability were investigated. 


\section{Experimental}

The experiments were performed with p-type $\left\{\begin{array}{lll}1 & 0 & 0\end{array}\right\}$ oriented microcrystalline silicon wafers obtained from Sino-American Silicon Products, Inc.

Before etching (texturization), the unpolished silicon wafer was cleaned by immersing it in aqueous HF solution $(<5 \mathrm{wt} \%)$ for $30 \mathrm{~s}$ to remove the native oxides from the silicon surface, followed by rinsing with deionized water and finally dried with nitrogen gas. The etching process was done by immersing the cleaned wafer into the etching solution which was maintained at the desired temperature for a specific etching time. Then, the wafer was immersed in $\mathrm{HNO}_{3}$ solution $(<10 \mathrm{wt} \%)$ to remove the adhering etchant solution, followed by rinsing with deionized water and drying using nitrogen gas.

Prior to etching with $\mathrm{Na}_{2} \mathrm{SiO}_{3}$ solutions, preliminary experiments were first conducted to assess the effectivity of various etchants in reducing the reflectance of the silicon surface. The etchants investigated were aqueous solutions of $\mathrm{NaOH}$ (2 wt\%), $\mathrm{Na}_{2} \mathrm{CO}_{3}$ (4.8 wt\%), $\mathrm{Na}_{3} \mathrm{PO}_{4} \cdot 12 \mathrm{H}_{2} \mathrm{O}$ (14 wt\%) and $\mathrm{Na}_{2} \mathrm{SiO}_{3}$ (5 wt\%). From which texturization by aqueous $\mathrm{Na}_{2} \mathrm{SiO}_{3}$ was found to yield the lowest value of the surface reflectance. The etching of the silicon wafer was then tested using aqueous solutions of $\mathrm{Na}_{2} \mathrm{SiO}_{3}$ of varied concentrations (2, 4, 6, 8 and $10 \mathrm{wt} \%)$ at different solution temperatures $(70-90)^{\circ} \mathrm{C}$ and etching times $(5-25)$ min. Experiments were also conducted using aqueous $\mathrm{Na}_{2} \mathrm{SiO}_{3}+$ IPA (0.03, 0.05, 0.1, 0.5 and $1 \mathrm{wt} \%$ ) solutions.

The surface reflectance was measured using a solar cell surface optical characteristics measurement system (MFS-630) from Yoli Kew Co. Ltd. The surface morphology was analyzed by a Scanning Electron Microscope, SEM (S-4700 type II) from Hitachi Co. Ltd.

\section{Results and Discussion}

\section{A. Preliminary evaluation of the effectivities of various etchants to reduce surface reflectance}

The choice of the etchant $\mathrm{Na}_{2} \mathrm{SiO}_{3}$ solution was based on the preliminary experiments conducted using a variety of known aqueous alkaline etchants: $\mathrm{NaOH}$ (2 wt\%), $\mathrm{Na}_{2} \mathrm{CO}_{3}$ (4.8 wt\%), $\mathrm{Na}_{3} \mathrm{PO}_{4} \cdot 12 \mathrm{H}_{2} \mathrm{O}$ (14 wt\%) and $\mathrm{Na}_{2} \mathrm{SiO}_{3}$ (5 wt\%). The silicon wafers were etched, separately, using these solutions at $80^{\circ} \mathrm{C}$ for $10 \mathrm{~min}$. The surface reflectances were measured and the morphologies of the etched wafers were determined. Results showed that texturization using aqueous $\mathrm{Na}_{2} \mathrm{SiO}_{3}$ yield the lowest value of the surface reflectance (Table I) at an etching rate of 0.384 $\mathrm{mg} \cdot \mathrm{cm}^{-2} \cdot \mathrm{min}^{-1}$ that was quite comparable to that of aqueous $\mathrm{NaOH}$. The low reflectance could be explained by the formation of more uniformly sized and shaped pyramids on the surface of silicon wafers etched using the latter as compared to those etched using the other three solutions such as observed in Fig. 1. These findings reveal the potential of aqueous $\mathrm{Na}_{2} \mathrm{SiO}_{3}$ solutions as promising etchants in the texturization of silicon wafers.
Table I. - Surface reflectance of wafers after anisotropic etching with various etchants for $10 \mathrm{~min}$ at $80^{\circ} \mathrm{C}$

\begin{tabular}{|c|c|c|}
\hline ETCHANT & $\begin{array}{c}\text { REFLECTANCE } \\
(\%)\end{array}$ & $\begin{array}{c}\text { ETCHING } \\
\text { RATE } \\
\left(\mathrm{mg} \cdot \mathrm{cm}^{-2} \cdot \mathrm{min}^{-1)}\right.\end{array}$ \\
\hline $\mathrm{NaOH}(2 \mathrm{wt} \%)$ & $15.07 \pm 0.16^{a}$ & 0.348 \\
\hline $\mathrm{Na}_{2} \mathrm{CO}_{3}(4.8 \mathrm{wt} \%)$ & $14.71 \pm 0.23$ & 0.089 \\
\hline $\begin{array}{l}\mathrm{Na}_{3} \mathrm{PO}_{4} \cdot 12 \mathrm{H}_{2} \mathrm{O} \\
(14 \mathrm{wt} \%)\end{array}$ & $10.96 \pm 0.10$ & 0.186 \\
\hline $\mathrm{Na}_{2} \mathrm{SiO}_{3}(5 \mathrm{wt} \%)$ & $10.35 \pm 0.30$ & 0.384 \\
\hline
\end{tabular}

${ }^{a}$ Standard deviation of three independent runs.

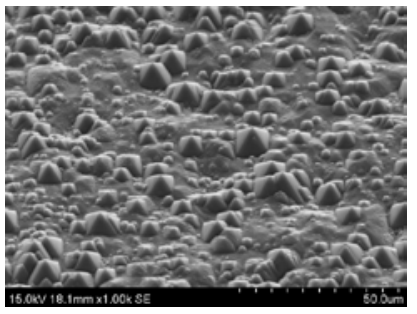

(a)

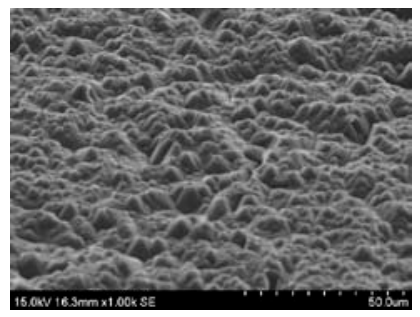

(c)

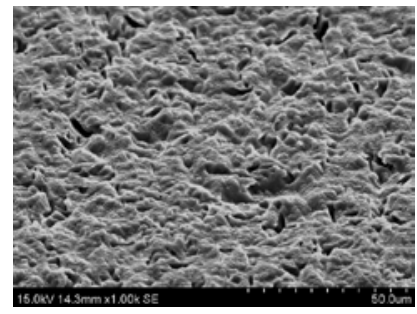

(b)

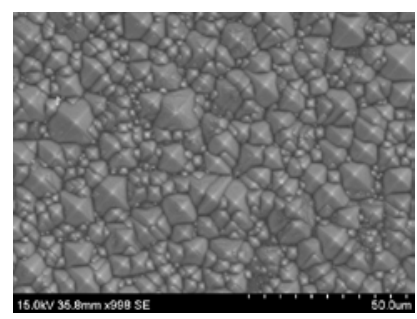

(d)
Fig. 1. SEM images of silicon wafers after anisotropic etching for 10 min at $80^{\circ} \mathrm{C}$ in aqueous solutions of: (a) $2 \%$ wt $\mathrm{NaOH}$; (b) $4.8 \mathrm{wt} \% \mathrm{Na}_{2} \mathrm{CO}_{3}$; (c) $14 \mathrm{wt} \% \mathrm{Na}_{3} \mathrm{PO}_{4} \cdot 12 \mathrm{H}_{2} \mathrm{O}$; (d) $5 \mathrm{wt} \%$ $\mathrm{Na}_{2} \mathrm{SiO}_{3}$.

B. Optimization of process conditions for wafer texturization using $\mathrm{Na}_{2} \mathrm{SiO}_{3}$ solutions

Effects of process parameters such as $\mathrm{Na}_{2} \mathrm{SiO}_{3}$ concentration, solution temperature and etching time on the reflectance of the silicon wafer surface were investigated. Initial evaluation was carried out by etching silicon wafers in different $\mathrm{Na}_{2} \mathrm{SiO}_{3}$ solutions and varying the solution temperatures and etching times. One-way analysis of variance (ANOVA) was applied as this allowed the evaluation of the effect of each parameter on the reflectance of the wafer. At a level of significance $(\alpha)$ of 0.05 , the analysis revealed that the etching temperature had no significant effect on the reflectance with a $P$-value of 1.0 whereas 0.037 and 0.033 were obtained for $\mathrm{Na}_{2} \mathrm{SiO}_{3}$ concentration and etching time, respectively. From the initial experiments, it was observed that etching at $80^{\circ} \mathrm{C}$ yield, relatively, the lowest reflectance of the wafer; thus, this temperature was used in the succeeding experiments.

The effects of the $\mathrm{Na}_{2} \mathrm{SiO}_{3}$ concentration and etching time were evaluated further. The results of the etching experiments are summarized in Table II. It can be observed that no systematic trend was observed 
pertaining to the effect of varying $\mathrm{Na}_{2} \mathrm{SiO}_{3}$ concentrations and etching times. Nonetheless, the lowest reflectance (9.35\%) was obtained from texturization by $6 \mathrm{wt} \%$ $\mathrm{Na}_{2} \mathrm{SiO}_{3}$ at $80^{\circ} \mathrm{C}$ for 5 min while the highest (13.96\%) was from texturization by $2 \mathrm{wt} \% \mathrm{Na}_{2} \mathrm{SiO}_{3}$ at $80^{\circ} \mathrm{C}$ for $15 \mathrm{~min}$.

Using the data presented in Table II, Response Surface Method (RSM) was applied to determine the optimum condition (having the lowest reflectance) for the etching process. By this method, the dependence of the reflectance on both the $\mathrm{Na}_{2} \mathrm{SiO}_{3}$ concentration and etching time was modeled via quadratic equation of the form

$$
\begin{aligned}
\text { Reflectance }_{\text {ave }} / \%= & 14.64-1.812 C+0.116 t \\
& +0.142 C^{2}-0.002 t^{2}-0.005 C t
\end{aligned}
$$

where $C$ is the concentration of $\mathrm{Na}_{2} \mathrm{SiO}_{3}$ in wt\% and $t$ the etching time in min. A 3D optimization plot (Fig. 2) was then generated from the results of the calculations using Eq. (1).

Table II. - Surface reflectance of wafers after anisotropic etching

\begin{tabular}{|c|c|c|}
\hline ETCHANT & $\begin{array}{c}\text { REFLECTANCE } \\
(\%)\end{array}$ & $\begin{array}{c}\text { ETCHING } \\
\text { RATE } \\
\left(\mathrm{mg} \cdot \mathrm{cm}^{-2} \cdot \mathrm{min}^{-1)}\right.\end{array}$ \\
\hline \multicolumn{3}{|c|}{2 wt $\% \mathrm{Na}_{2} \mathrm{SiO}_{3}$} \\
\hline 5 & $13.32 \pm 0.32$ & 0.220 \\
\hline 10 & $13.65 \pm 0.34$ & 0.160 \\
\hline 15 & $13.96 \pm 0.59$ & 0.137 \\
\hline 20 & $13.02 \pm 0.52$ & 0.136 \\
\hline 25 & $12.08 \pm 0.18$ & 0.134 \\
\hline \multicolumn{3}{|c|}{$4 \mathrm{wt} \% \mathrm{Na}_{2} \mathrm{SiO}_{3}$} \\
\hline 5 & $12.78 \pm 0.50$ & 0.389 \\
\hline 10 & $9.62 \pm 0.01$ & 0.328 \\
\hline 15 & $10.40 \pm 0.05$ & 0.279 \\
\hline 20 & $10.45 \pm 0.36$ & 0.256 \\
\hline 25 & $10.73 \pm 0.16$ & 0.244 \\
\hline \multicolumn{3}{|c|}{$6 \mathrm{wt} \% \mathrm{Na}_{2} \mathrm{SiO}_{3}$} \\
\hline 5 & $9.35 \pm 0.27$ & 0.477 \\
\hline 10 & $9.47 \pm 0.27$ & 0.391 \\
\hline 15 & $9.69 \pm 0.09$ & 0.322 \\
\hline 20 & $10.09 \pm 0.10$ & 0.300 \\
\hline 25 & $10.43 \pm 0.06$ & 0.285 \\
\hline \multicolumn{3}{|c|}{8 wt $\% \mathrm{Na}_{2} \mathrm{SiO}_{3}$} \\
\hline 5 & $10.68 \pm 0.59$ & 0.539 \\
\hline 10 & $10.30 \pm 0.22$ & 0.461 \\
\hline 15 & $10.41 \pm 0.12$ & 0.379 \\
\hline 20 & $10.48 \pm 0.12$ & 0.359 \\
\hline 25 & $10.63 \pm 0.12$ & 0.337 \\
\hline \multicolumn{3}{|c|}{$10 \mathrm{wt} \% \mathrm{Na}_{2} \mathrm{SiO}_{3}$} \\
\hline 5 & $11.54 \pm 0.68$ & 0.671 \\
\hline 10 & $11.14 \pm 0.08$ & 0.572 \\
\hline 15 & $10.48 \pm 0.13$ & 0.505 \\
\hline 20 & $10.57 \pm 0.15$ & 0.471 \\
\hline 25 & $10.66 \pm 0.13$ & 0.441 \\
\hline
\end{tabular}
using various etchants for $10 \mathrm{~min}$ at $80^{\circ} \mathrm{C}$
As shown in Fig. 2, the optimum concentration of $\mathrm{Na}_{2} \mathrm{SiO}_{3}$ and etching time were at $6.2 \mathrm{wt} \%$ and $5 \mathrm{~min}$, respectively. Thus, the optimization of the process variables yield the condition: $C=6.2 \mathrm{wt} \%, T=80^{\circ} \mathrm{C}$ and $t=5 \mathrm{~min}$. This optimum process condition was finally used in the texturization of the silicon wafer. The reflectance of the etched wafer was found to be $9.27 \%$. This low value of the reflectance is a manifestation of the dense, uniformly distributed pyramid structures formed on the surface of the silicon wafers upon texturization. The SEM image of the wafer textured at the optimum condition is shown in Fig. 3.

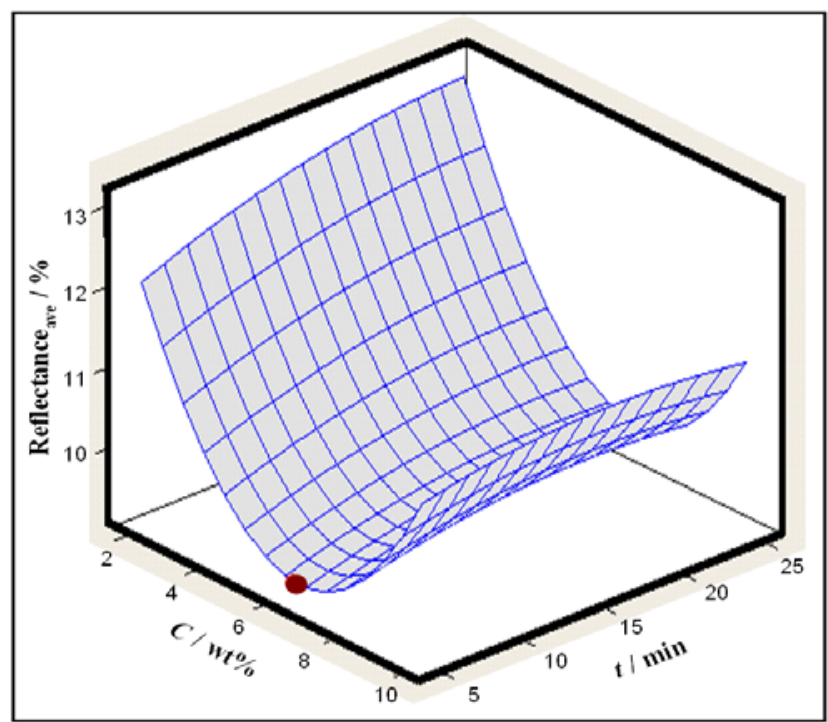

Fig. 2. Reflectance of silicon wafer as a function of $\mathrm{Na}_{2} \mathrm{SiO}_{3}$ concentration and etching time: red dot represents the optimum condition [as calculated from Eq. (1)].

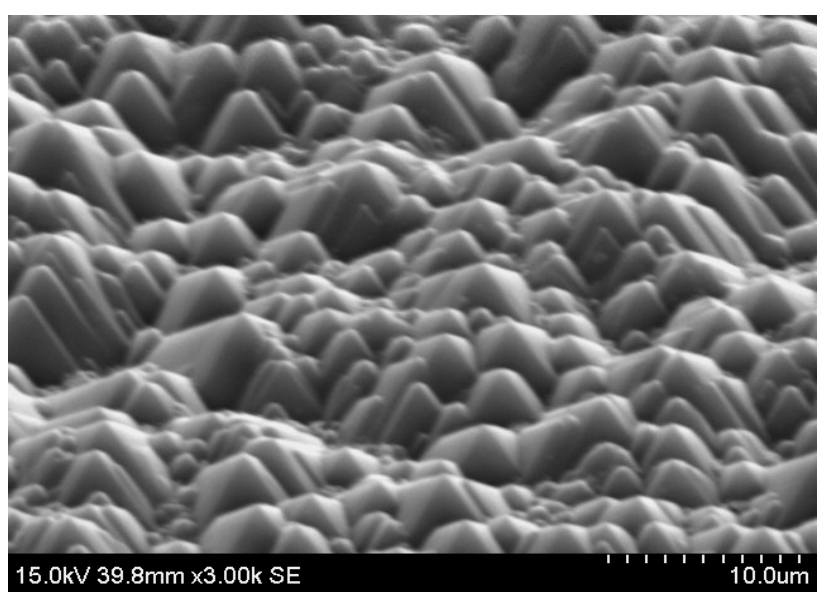

Fig. 3. SEM image of the silicon wafer after anisotropic etching with $6.2 \mathrm{wt} \% \mathrm{Na}_{2} \mathrm{SiO}_{3}$ at $80^{\circ} \mathrm{C}$ and 5 min.

It is also apparent that the reflectance of the etched wafer is affected by the etching rate. The lowest value of the etching rate obtained was $0.160 \mathrm{mg} \cdot \mathrm{cm}^{-2} \cdot \mathrm{min}^{-1}$ (textured by $2 \mathrm{wt} \% \mathrm{Na}_{2} \mathrm{SiO}_{3}$ at $80^{\circ} \mathrm{C}$ for $10 \mathrm{~min}$ ) while the highest was $0.671 \mathrm{mg} \cdot \mathrm{cm}^{-2} \cdot \mathrm{min}^{-1}$ (textured by $10 \mathrm{wt} \% \mathrm{Na}_{2} \mathrm{SiO}_{3}$ at $80^{\circ} \mathrm{C}$ for $5 \mathrm{~min}$ ). As shown in Fig. 4, generally, low reflectance values were obtained at etching rates $0.3-0.5$ $\mathrm{mg} \cdot \mathrm{cm}^{-2} \cdot \mathrm{min}^{-1}$. In this range, the reflectance values were less than $11 \%$. 


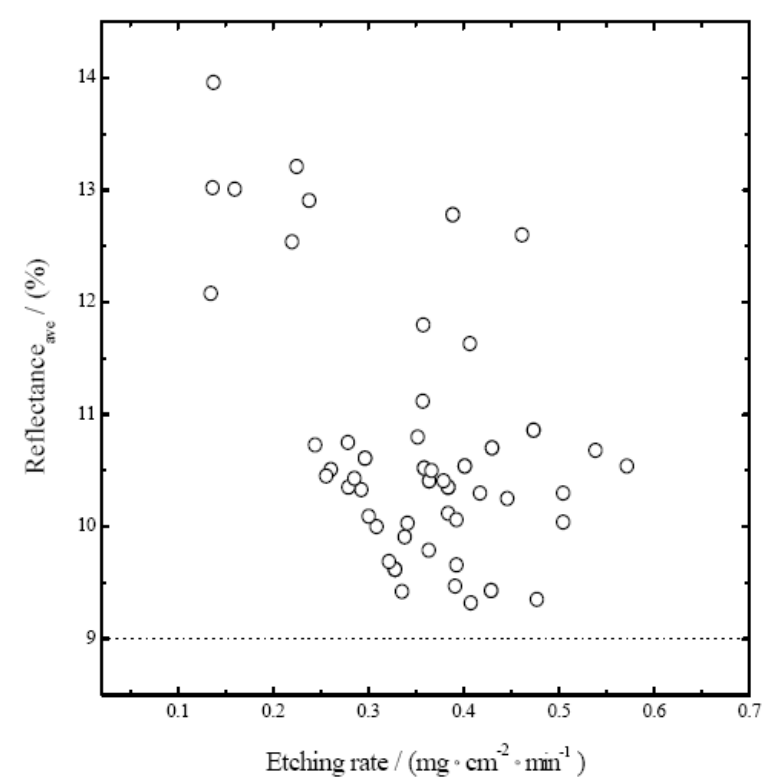

Fig. 4. Reflectance of the textured silicon wafers as a function of etching rate.

\section{Addition of IPA to etching solutions}

In industrial applications, one problem in the texturization of silicon wafers is the formation of bubbles that adhere on the wafer's surface and inhibiting its texturization. A study reported that the addition of IPA increases the wettability of the silicon surface resulting in the removal of the adhering bubbles [2]. Thus, in this study, we considered the addition of IPA in concentrations $(0.03,0.05,0.10$, 0.50 and 1.0 wt\%) to the $6.2 \% \mathrm{Na}_{2} \mathrm{SiO}_{3}$ solution and investigated its effect on the texturization of the silicon wafer. After etching at $80^{\circ} \mathrm{C}$ and $5 \mathrm{~min}$, the reflectance of the silicon surface was measured and the contact angle was determined via Magic Drop (model 2000) to assess its wettability. The results of the analyses are summarized in Table III along with the etching rates. Results showed that only a small amount of IPA was necessary to improve the reflectance of the silicon surface. Addition of up to $0.03 \%$ IPA to the $6 \mathrm{wt} \% \mathrm{Na}_{2} \mathrm{SiO}_{3}$ solution resulted in decreased reflectance of the textured wafer (from $9.27 \%$ to $9.13 \%$ ). However, when added in higher concentrations, IPA increased the reflectance of the silicon surface. It was also apparent that as the concentration of IPA was increased in the solution, the etching rate decreased. These indicate that IPA has detrimental effects on the texturization of silicon wafers using $\mathrm{Na}_{2} \mathrm{SiO}_{3}$ when used in high concentrations. Nonetheless, the IPA seemed to improve the wettability of the surface as evidenced by the decreasing values of the contact angle as the IPA concentration increased. It is also worthy to note that the addition of IPA to $6.2 \mathrm{wt} \%$ $\mathrm{Na}_{2} \mathrm{SiO}_{3}$ to only up to 0.03 wt\% did not significantly improve the wettability of the surface. It can be said that using the $\mathrm{Na}_{2} \mathrm{SiO}_{3}$ solution without IPA would be a viable choice since IPA also pose some disadvantages in the texturization process.
Table III. - Effects of IPA on the texturization of silicon wafers using $6.2 \mathrm{wt} \% \mathrm{Na}_{2} \mathrm{SiO}_{3}+\mathrm{IPA}$ at $80^{\circ} \mathrm{C}$ and $5 \mathrm{~min}$.

\begin{tabular}{|c|c|c|c|}
\hline $\begin{array}{c}\text { IPA } \\
\text { CONC. } \\
\text { (wt\%) }\end{array}$ & $\begin{array}{c}\text { REFLECTANCE } \\
(\%)\end{array}$ & $\begin{array}{c}\text { ETCHING } \\
\text { RATE } \\
\left({\mathrm{mg} \cdot \mathrm{cm}^{-2} .}^{\left.\mathrm{min}^{-1}\right)}\right.\end{array}$ & $\begin{array}{c}\text { CONTACT } \\
\text { ANGLE } \\
\left({ }^{\circ}\right)\end{array}$ \\
\hline 0 & $9.27 \pm 0.27$ & 0.486 & 38.6 \\
\hline 0.03 & $9.13 \pm 0.09$ & 0.461 & 37.7 \\
\hline 0.05 & $9.58 \pm 0.06$ & 0.448 & 37.3 \\
\hline 0.10 & $10.16 \pm 0.13$ & 0.412 & 36.1 \\
\hline 0.50 & $11.53 \pm 0.11$ & 0.373 & 26.9 \\
\hline 1.00 & $12.13 \pm 0.12$ & 0.340 & 22.5 \\
\hline
\end{tabular}

\section{Conclusion}

Texturization of monocrystalline silicon wafer for solar cells using aqueous $\mathrm{Na}_{2} \mathrm{SiO}_{3}$ solutions as etchant was successfully carried out. Results showed that $\mathrm{Na}_{2} \mathrm{SiO}_{3}$ solutions can reduce the surface reflectance of the wafers better than other alkaline etchants. The effects of process parameters such as $\mathrm{Na}_{2} \mathrm{SiO}_{3}$ concentration, solution temperature and etching time on the reflectance of the wafer were evaluated and process optimization was carried out. Using one-way ANOVA, the solution temperature was found to have no significant effect on the reflectance. Using RSM, the optimum condition (to obtain the lowest reflectance) for the etching process was determined to be: 6.2 wt $\% \mathrm{Na}_{2} \mathrm{SiO}_{3}$, solution temperature $=80^{\circ} \mathrm{C}$ and etching time $=5$ min where the reflectance of the silicon wafer was reduced to $9.27 \%$. SEM images showed that the texturization of the silicon surface by the $\mathrm{Na}_{2} \mathrm{SiO}_{3}$ solutions resulted in the formation of uniformly distributed pyramidal structures on the surface of the wafer. Furthermore, the addition of small amounts IPA (up to 0.03 wt\%) to the $\mathrm{Na}_{2} \mathrm{SiO}_{3}$ solution reduced the reflectance of the wafer and slightly increased its wettability.

\section{References}

[1] B. Vallejo, M. Gonzales-Manas, J. Martinez-Lopez and M.A. Caballero, "On the texturization of monocrystalline silicon with sodium carbonate solutions”, Sol. Energy 2007, Vol. 81, pp. 565-569.

[2] H. Li, W. Liu, A. Liu, F. Qiao, Z. Hu and Y. Liu, "Metal grids-based texturization of monocrystalline silicon wafers for solar cells”, Sol. Energ. Mat. Sol. C. 2007, Vol. 81, pp. 565-569.

[3] B. Nayak, V. Iyengar and M. Gupta, "Efficient light trapping in silicon solar cells by ultrafast-laserinduced self-assembled micro/nano structures”, Prog. Photovolt: Res. Appl. 2001, Vol. 19, pp. 631639.

[4] Z. Xi, D. Yang, W. Dan, C. Jun, X. Li and D. Que, "Investigation of texturization for monocrystalline silicon cells with different kinds of alkaline", Renew. Energ. 2004, Vol. 29, pp. 2101-2107.

[5] P. Papet, O. Nichiporuk, A. Kaminski, Y. Rozier, J. Kraiem, J. Lelievre, A. Chaumartin, A. Fave and M. Lemiti, "Pyramidal texturing of silicon solar cell with TMAH chemical anisotropic etching ”, Sol. Energ. Mat. Sol. C. 2006, Vol. 90, pp. 2319-2328. 